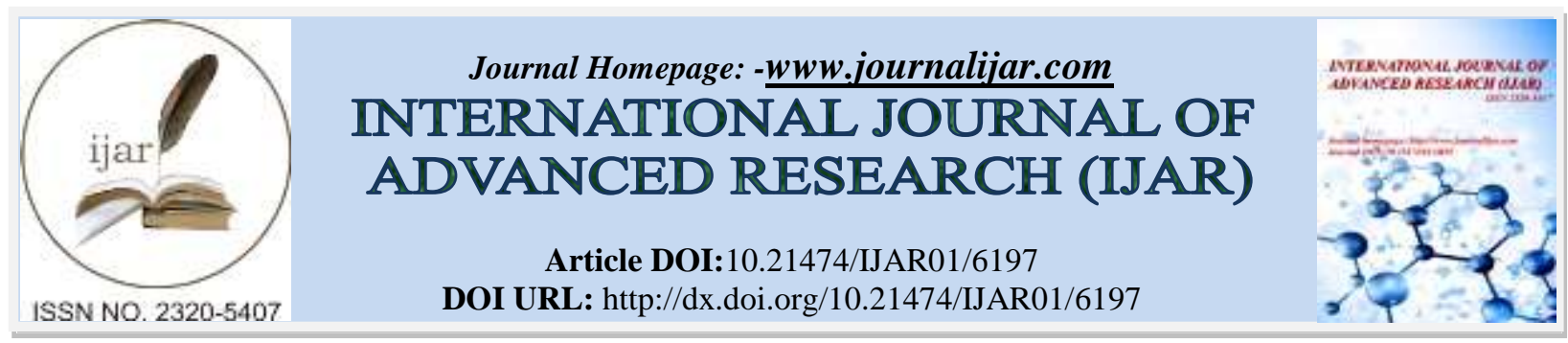

RESEARCH ARTICLE

\title{
IMMUNITIES AND PRIVILEGES OF UN AGENCIES IN ETHIOPIA: PROBLEMS AND POSSIBLE REMEDIES.
}

Yohannes Tessema Gerbi.

\section{Manuscript Info}

Manuscript History

Received: 03 November 2017

Final Accepted: 05 December 2017

Published: January 2018

Keywords:-

Immunities and Privileges, UN agencies,

Convention, Mediation, Human rights.

\begin{abstract}
Ethiopia was founding members of UN and a host country for more than one hundred diplomatic missions including UN agencies. It was a party to the 1946 Convention on Immunities and Privileges of UN agencies which bares domestic Courts from exercising jurisdiction concerning disputes involving UN agencies. This creates a vacuum of alternative legal remedy available for Ethiopian citizens to seek justice in disputes that involve UN agencies. The inadqency of the Convention in settling abuses of immunities leads to violation of right to justice in Ethiopia. The problem initially arises due to the provisions of the Convention which provides immunity from any form legal process of domestic judicial jurisdiction. This gave room for rogue officials and staffs to engage in civil and criminal activities for private interests.Lack of judicial jurisdiction on immuned and privileged persons resulted in abuses of rights in Ethiopia. Due to lack of immunity act and absence of effective remedy to claimants, individual's right violated because of unable to claim their right against illegal act done by persons enjoying immunity. This article attempt to explore problems related to implementation of immunities and privileges of UN agencies in Ethiopia and examine available remedies for individuals abused by immunities of UN agencies.
\end{abstract}

Copy Right, IJAR, 2018,. All rights reserved.

\section{Introduction:-}

United Nation is a universal organization primarily entrusted with preservation of international peace and security. ${ }^{1}$ Following the end of World War II major powers acknowledged the important role that UN agencies can play in promoting international peace and cooperation. Article 105 of the Charter states that the UN shall enjoy in the territory of each of its members such privileges and immunities as are necessary for the fulfillment of its purposes and independent exercise of their functions in connection with the organization. ${ }^{1}$ The generality the charter necessities further more precise Convention for practical application in detail form called Convention on the Privileges and Immunities of the UN. Article 2 section 2 and 3 of the 1946 Convention states that, UN's property and assets wherever located and by whomsoever held, shall enjoy immunity from every form of legal process except in sofar as in any particular case it has expressly waived its immunity. ${ }^{2}$ The premises of the UN shall be inviolable, property and assets of UN wherever located and whosoever held, shall be immune from search, requisition, confiscation, expropriation and any other form of interference, whether by executive, administrative, judicial or

\footnotetext{
${ }^{1}$ Id at pp-19

${ }^{2}$ Convention on Immunitiesand Privileges of the United Nations, 13 February 1946, Art, 2.
} 
legislative action. ${ }^{3}$ In addition to this the Convention obliges state parties to refrain from exercising judicial jurisdiction on officials and staffs of UN agencies.

Ethiopia, as a party to the Convention can't exercise judicial jurisdiction on UN agencies and their staffs who enjoy immunity under the Convention. Host state laws are actually applicable on UN agencies but Ethiopia lacks domestic immunity act that regulate the relationship between its citizens with international organization. ${ }^{4}$ However, in recent years misunderstandings have occurred that resulted in the violation of UN staff privileges and immunities through arrest and detention in many parts of Ethiopia. As a result the UN staffs feel unprotected and unprivileged. On the other hand many Ethiopian citizens right to justice was violated by UN agencies because of the Convention bare courts not to adjudicate cases that involve UN agencies. This creates a vacuum of legal remedies available for individuals which involved in dispute with UN agencies. A large part of this undeniable individuals has only very limited means of brining their claim before a judicial body able to issue binding judgments in disputes involving the $\mathrm{UN}$ respondent. ${ }^{5}$ It became increasingly difficult for $\mathrm{UN}$ agencies to rely on immunity in proceeding before courts if individuals thereby suffer a complete denial of justice due to absence of adequate alternative legal remedies to Ethiopian citizens. ${ }^{6}$

The immunity and privileges granted to UN agencies by the Convention is functional in nature. ${ }^{7}$ They enjoy privileges and immunities only for those acts which are closely related to their organizational purpose. However, the extent of their functional immunity and privileges are not clear. The only available legal remedy to Ethiopian claimants is mediation in Ministry of Foreign Affairs as per section 29 of the Convention. The mediation processes is not effective, efficientand lacks legal groundto render a binding decision. Individual's right to seek justice on one side and obligation of Ethiopia to respect and guarantee immunities and privileges of UN agencies are nowadays the problem likely to continue.

The article has employed qualitative research methodology. The sources of this article are both primary and secondary data which employed to investigate various issues through analysis and explanation of legal concepts and court decisions. Primary data was gathered by semi-structured interviews and additionally from conventions, treaties, laws, head quarter agreements and court cases.Secondary data was collected and analyzed from selected literatures such astext books, journals, websites, scholarly articles, bar reviews, magazines, reports, news papers and unpublished theses. Court cases and interviewees persons were selected based on the purpose of the article and relevance to the issue by snowball sampling technique. The article is not concerned with diplomatic immunities and privileges of Embassies and Consular Missions governed by 1961 Vienna Convention on diplomatic relations.

\section{Immunities and Privileges in General:-}

There is no internationally agreed definition of immunities and privileges of international organization. But from legal point of view the concise black's law dictionary defines immunity as exemption or protection from an obligation or penalty. ${ }^{8}$ On the other hand privileges are special right, advantage, or benefit for a particular person or organization exemption from a liability or obligations. ${ }^{9}$ From this we can conclude that immunities and privileges are exemption from national jurisdiction granted by authorities or states. The immunities and privileges of international organizations is recent phenomenon. ${ }^{10}$ Immunities and privileges given to international organization built on different legal systems and the extent of application is also different. ${ }^{11}$ However diplomatic immunity and immunities and privileges of international organization seem similar but they manifested differently.

\footnotetext{
${ }^{3}$ Id, Article, 3 .

${ }^{4}$ Miller, (2009), The privileges and immunities of the United Nations, International Organizations law Review, at pp. 2

${ }^{5}$ August Reinisch, UN Immunity and access to dispute Settlements, International Law Seminar, Institute of International Law University of Vienna, Fall Semester 2010/11 at P- 1.

${ }^{6}$ Id .pp. 3.

${ }^{7}$ Id.pp. 4

${ }^{8}$ Black's Law Dictionary 778 ( $8^{\text {th }}$ ed. 2004).

${ }^{9}$ Id.pp.587

${ }^{10}$ Drazen Petrovic, Privileges and Immunities of UN Specialized Agencies in Filed activity (Preliminary Paper), (June 25, 2009) Practical Legal Problems of International Organizations, A Global Administrative Law on Public/ Private Partnerships, Accountability, and Human Rights, pp.1

${ }^{11}$ Ibid
} 


\section{Theoretical Basis for Immunities and Privileges of International organizations:-}

Various theories have been developed to explain immunities and privileges of international organizations. Among this the main traditional theoretical justifications for diplomatic immunity are extra- territoriality, personal representation, and functional necessity. ${ }^{12}$

\section{The Extraterritoriality Theory:-}

The theory of extraterritoriality suggests that the property of a diplomat and the person of the diplomat are to be treated as if they exist on the territory of the sending state. ${ }^{13}$ According to Wanyela, the diplomat legally resides on the soil of sending state despite the fact that the diplomat lives abroad. Because the diplomat is considered to be living in the sending state, he/she remains immune from the criminal and civil jurisdiction of the receiving state. Wilson argues this theory is ironic, considering that the diplomat would not be immune for the same illegal conduct if committed in the sending state. Not surprisingly, this theory has been described as a legal fiction, and received widespread support from international scholars and judicial opinion recently questioned and rejected this theory with view that it is too expensive, excessive and it prevents states from restricting the privileges and immunities of diplomats. ${ }^{14}$

\section{The Personal Representation Theory:-}

The personal representation theory is premisedontheideathatthediplomatisrepresentativeofasovereignstate, and thatastherepresentativehe/sheisentitledtothesameprivilegesas thesovereign. This theory enjoyed a greatest popularity in the 18th and 19th century. ${ }^{15}$ under this theory the diplomat assumes the role the head of the sending state or the sovereign power of the state. This theory, like extraterritoriality, is not widely accepted in modern diplomatic practice. ${ }^{16}$ It is criticized because in many states there is no longer a monarchy and sovereignty has been transferred to the people and their elected officials. ${ }^{17}$ Because people do not enjoy immunity from prosecutioninforeign states, their representativesshouldnoteither. ${ }^{18}$ Inaddition, the personal representation theory offers no justification for why diplomats should be immune from jurisdiction for their private acts. ${ }^{19}$ This theory also fails to limit the scope of diplomatic immunity and it is against the very purpose of immunity which is to facilitate international discourse.

\section{The Functional Necessity Theory:-}

Functional necessity is the most accepted theory for the justification of diplomatic immunity. ${ }^{20}$ under this theory, privileges and immunities should be limited to those necessary for the diplomat to carry out his/her official functions. ${ }^{21}$ The justification for granting immunities to diplomatic agents is based on the need to enable normal functioning of diplomatic missions and diplomats. Indeed, functional necessity theory has been acknowledged in theViennaConventionon Diplomatic relations, UN charter and the 1946 Convention on immunities and privileges of United Nations. ${ }^{22}$ This theory, however, has been provenviable under the 1946 UN Convention. ${ }^{23}$ While functional immunity is the most accepted theory of diplomatic immunity, it is not without its shortcomings. For example, if functional necessity was fully implemented in the diplomatic context, who determines what, constitutes an official function? Would all official acts becovered? Once immunity is limited to covering official acts, would otherimmunitiesbefurthereroded? These are questions with potential solutions, and therefore, the theory of functional necessity presents the best opportunity for limiting diplomatic immunity. ${ }^{24}$

\section{The Origin and History of Immunities and Privileges of UN Agencies:-}

Prior to the end of Second World War, the concept of privileges and immunities of international organizations had not been widespread. ${ }^{25}$ They have often been determined on a bilateral basis through headquarters agreements. As Jenks concluded," historically, the present content of international immunities derives from the experience of the League of Nations as developed by the International Labor Organization when submitted to the test of war time conditions, reformulated in certain respects in the ILO-Canadian wartime arrangements, and subsequently reviewed by the General Assembly of the United Nations at its first session in $1946 " .{ }^{26}$ International immunities first appeared

\footnotetext{
${ }^{12}$ Charity Simuli Wanyela, (2014), Diplomatic Privileges and Immunities: A Critical Analysis of the Vienna Convention on Diplomatic Relations (1961),(Unpublished LL.M Research Paper, University of Nairobi), at, pp.6.

${ }^{13}$ Id. pp. 4.

${ }^{14}$ Id. pp. 33.
} 
during the $19^{\text {th }}$ Century, even though the development of international organizations did not begin to drastically increase until the postWorld WarII period. ${ }^{27}$ The situation created by the Second World War gave new impetus to the development of international organizations. ${ }^{28}$ This resulted creation of many international organizations such as International Postal Union, ICA, IBRD, IMF, FAO, UNESCO, and WHO.

This misapplication of diplomatic immunity to officials working in international or generations created doctrinal confusion, because the international official's primary duty was to represent the organization, not their home state. ${ }^{29}$ This misapplication had a dual effect. First, international officials were susceptible to pressure by their own state to work toward the state's interests rather than the international organizations, and second, the extension of absolute immunity to this category of individuals risked undermining their accountability for private acts. ${ }^{30}$ Recognizing the doctrinal confusion, the drafters of the UN Charters ought to avoid this by adopting functiona limmunities and privileges for the organization and its officials which resulted in creation of two conventions in 1946 and 1947. The drafting of the Convention on the Privileges and Immunities of the UN was proposed by the Preparatory Commission of the UN. ${ }^{31}$

The Preparatory Commission recommended to the General Assembly that it should propose such a convention pursuant to Articles 104 and 105 of the UN Charter. On February13, 1946 the General Assmibly, on the advice and counsel of the Sixth (Legal) Committee and the Sub-Committee on Privileges and Immunities, adopted Resolution which approved the text of the Convention and proposed it for accession by member States. ${ }^{32}$

\section{The Legal Frameworks for Immunities and Privileges of UN agencies:-}

The United Nations Charter, (1945):-

After the end of World War II in 1945, to save succeeding generation from scourge of war, to reaffirm faith in fundamental human right and to maintain international peace and security world states established United Nations in San Francisco. ${ }^{33} \mathrm{UN}$ is the biggest global international organization in terms of membership. Following its establishment $\mathrm{UN}$ creates different principal organs and specialized agencies in order to accomplish its objective. At the time of establishment it was considered as necessary that it should enjoy the status of a legal person under domestic law of its member states. Such domestic legal personality is a prerequisite for the organization to effectively exercise its function. ${ }^{34}$ Due to this UN Charter responded in a very general way in article 104 of the charter by saying that "the organization shall enjoy in the territory of each of its member such legal capacity as may be necessary for the exercise of its functions and he fulfillment of its purpose".

These abstract rules required some more detailed explanation in order to become workable helping UN officials as well as national courts to determine whether the UN should be considered capable of entering into a specific legal transaction or immune from a particular lawsuit directed against it. ${ }^{35} \mathrm{In}$ a similar way it was unclear to what extent UN officials and member state representatives to the United Nations should enjoy privileges and immunities. In article 105, paragraph 2, the drafters of the Charter opted for a functional concept when it was stated therein that " representatives of the member of the United Nations and officials of the organization shall similarly enjoy such privileges and immunities as are necessary for the independent exercise of their functions in connection with the organization." ${ }^{36}$

The Conventionon the Privileges and Immunities of UN Agencies (1946):-

International immunity described as the immunity enjoyed by international organizations and their personnel. ${ }^{37}$ Articles 104 and105 of the UN Charter provide the framework for the development of the privileges and immunities of the organization and its officials. International immunities of UN officials are premised on functional necessity as articulated in Article 105 (2) of the UN Charter. On February 13, 1946, the UN General Assembly adopted the Convention on the Privileges and Immunities of the UN. It entered in force on 17 September $1946 .{ }^{37}$ There are currently 157 states parties to the convention out of 192 members of UN including Ethiopia. This Convention set for the system of privileges and immunities of the organization, to more fully define the concept of privileges and immunities characterized in the Charter. ${ }^{38}$ Pursuant to Article 105 of the UN Charter, the UN Convention, unlike the Vienna Convention, limits the privileges and immunities of UN officials to those thatare "necessary for the independen texercise of their functions inconnection with the Organization." ${ }^{39}$ Thus, the theory of functional necessity is carried to its logical conclusion in the UN Convention. ${ }^{40}$ By uniformly applying the 
functional approach to immunity; the UN Convention prevents officials from abusing immunities for personal benefit.

The main objective of the Convention is to establish a legal framework for protection of immunities and privileges United Nations staffs. ${ }^{41}$ The purpose of this Convention is to give certain detailed privileges and immunities to the United Nations as an Organization, as well as to the representatives of Member States, officials of the United Nations and experts on mission for the United Nations. The privileges and immunities of Member representatives to the principal and subsidiary organs of the United Nations and to conferences convened by the United Nations are governed by article IV of the General Convention. ${ }^{42}$

\section{The Convention on Privileges and Immunities of UN Specialized Agencies (1947):-}

The 1946 General Convention has had a major impact on the development of subsequent treaties dealing with privileges and immunities of international organizations. ${ }^{43}$ On 21 November 1947, the GA approved the Convention on the Privileges and Immunities of the Specialized Agencies. ${ }^{44}$ It entered into force on 2 December 1948 and applies to those United Nations related international organizations that have entered into special relationship agreements with the UN pursuant to Article 63 of the Charter, such as the International Civil Aviation Organization, WHO, FAO, UNESCO, IMF, IBRD and others. ${ }^{45}$ Unlike Ethiopia, it has a total of 116 state parties. Each state party has to indicate in its instrument of accession the specialized agencies in respect of which it undertakes to apply the provisions of this convention. ${ }^{46}$ This Special Convention contains roughly the same provisions on privileges and immunities as the General Convention. ${ }^{15}$ Examples of similar privileges and immunities treaties are the General Agreement on Privileges and Immunities of the Council of Europe, 1949, and the Agreement on Privileges and Immunities of the Organization of American States, 1949. Numerous "headquarters" or "seat agreements" have also been influenced by the General Convention. ${ }^{47}$ Both conventions cover three types of privileges and immunities, those accorded to the organization itself, to representative of member and to the staff of the secretariat. ${ }^{48}$

\section{The Vienna Conventionon Diplomatic Relations (1961):-}

The VCDR was signed on April 18, 1961 and entered in to force on April 24, 1964.16It is these minaltreaty governing diplomatic relations. ${ }^{49}$ The Vienna Convention contains 53 articles that govern the behavior of diplomats, thirteen of which address the issue of immunity. ${ }^{50}$ The preamble of the Vienna Convention acknowledges the theory of functional necessity. I states that the purpose of the Convention is " the development of friendly relations among nations, irrespective of their differing constitutional and social systems,"and that the purpose of providing privileges and immunities"is not to benefi tindividuals but to ensure the efficient performance of the functions of diplomatic missions as representing States". ${ }^{51}$ While it recognizes that immunity is not for the personal benefit of the diplomat,it stops short of fully adopting the theory of functional necessity.

\section{The Host Country Agreements (HQA):-}

In addition to above conventions host state agreements signed between each UN organizations with host countries are also sources of immunities and privileges for many UN agencies. International organizations lack a territory of their own, and thus depend on the sovereign state to perform their functions. When a state enters in to a head quarter agreement with them, it is allowing the international organizations to operate in its territory. After this the hosting state is under obligation to respect the autonomy of the international organization to function in its territory.

\section{Why Immunities and Privileges for UN agencies:-}

UN agencies have been given many tasks by their constituent documents. Members are separated from organizations, but organization has its own objective, bear its own rights and duties separately from their founders. Their internal matters like administration of staff, property and finance transaction with third party shall not be regulated by domestic law of member states. ${ }^{52}$ States and their representatives enjoy a variety of privileges and immunities. The reason for granting immunities and privileges for UN agencies was to enable them to pursue their function more effectively and to permit organization to freely operate without control by host country. ${ }^{53}$ In order to fulfill their functions they need autonomy from outside influence. This requires the conferment of international legal

\footnotetext{
${ }^{15}$ Ibid

${ }^{16}$ Vienna Convention on Diplomatic Relation, Apr. 8, 1961,23 U.S.T. 3227, 500 U.N.T.S.95 (Herein after Vienna Convention); Lori J. Shapiro, foreign relations law: modern development in diplomatic Immunity, 1989 Ann. Surv. Am. L.281, 295.
} 
personality to organizations in order to effectively perform their tasks independently from interference by host state. $^{54}$

\section{Types of Privileges and Immunities and Persons Exempted:-}

The first part of the Convention consists of so called "standard clauses". 55 The Convention set out the category of persons who have been conferred the privileges and immunities, and types of immunities and privileges. The general Convention contain immunities and privileges for three categories of persons crucial for the organization such as the organization itself, representatives of member states, UN officials, staffs and experts on the missions for United Nations.

\section{Persons Exempted:- Immunity from Legal Process:-}

The premises and property of the United Nations organizations are exempted from search, seizer, confiscation and other form of interference by host state. In this regard, article 2 Section 2 of the 1946 Convention sets out that the premises, archive, property and asset of UN organization are inviolable from every form of legal process. ${ }^{56}$ The exemption as provided impliedly is not limited to the member states only. The phrase "whenever located" may denote the extension of this obligation to non member state. ${ }^{57}$ Furthermore, article 2 section 3 of this convention states that, "The premises of the United Nations shall be inviolable. The property and assets of the United Nations, wherever located and by whom ever held, shall be immune from search, requisition, confiscation, expropriation and any other form of interference, whether by executive, administrative, judicial or legislative action". This part of the standard clauses was drafted in rather absolute terms. Domestic authorities can exercise their jurisdiction only if the immunity is waived by the organizations. 58

The rationale behind of these immunities and privileges is to avoid partiality and interference by host country besides financial burden by a member state. Consequently, the host country authorities cannot enter the UN premise without the permission of the organization for whatsoever. In view of this, the host country is under obligation to protect the premise of the UN. Article II, section 4 of the 1946 Convention provides the inviolability of the archives of the United Nation Organization. Therefore, it describes that "the archives of the United Nations, and in general documents belonging to it or held by it, shall be inviolable wherever located".

\section{Exemption from Fiscal Regulation:-}

As per article 2 section 5 and 7 the Convention, UN agencies are exempted from financial regulations of a host country. These privileges and immunities include exemption from direct taxation, custom duties, and import and export restrictions, opening dollar account, and free transfer of funds. The UN can own funds, gold, or currency of any kind, and operate accounts in any currency without being restricted by financial control of a host country. It can also freely transfer from one country to another and convert from one currency to another. In relation to financial restriction, the UN enjoys favorable rates of exchange. ${ }^{59}$ The rationale behind of these immunities and privileges is to avoid additional financial burden by a member state as organizations are established for non- profit objectives, besides autonomy given to the UN from jurisdiction of the host country. However, the Convention sets out exception for public utility charges. As far as the other category of taxes are concerned, like indirect taxes (excise tax, sales tax, VAT, stamp tax) since the underlying objective of exemption is to prohibit financial burden of the organization, and thus, the exemption is intended to cover the entire fields of taxes. ${ }^{60}$ Moreover, the characterization given to a tax in a particular municipal law system cannot be controlling in the application of the provision of the Convention on the Privileges and Immunities of the United Nations which must be interpreted uniformly in respect of all member states. ${ }^{61}$

\section{Freedom of Communications:-}

UN agencies enjoy full freedom of communications in the territory of the host country. ${ }^{62}$ They use codes and diplomatic mail for their official communications. For the purpose of communications, the UN receives papers or correspondence by courier or in sealed bags. ${ }^{63}$ In this regard, the 1947 Convention refers to diplomatic law. Consequently, it can be argued that it has to be respected even in the absence of host country agreement on the basis of customary international law. Thus, host country shall not restrict communications. All UN agencies are administered centrally in terms of budget, personnel and humanitarian assistance which require immediate response. These all require the use of advanced technology. In relation to this, various head quarter agreements contain provisions of relating to host country protection of the UN's unrestricted freedom of communication. 


\section{Immunities and Privileges accorded to Representatives of Member States:- Immunity from Legal Process:-}

Representative of member state who attends a meeting convened by a specialized agency enjoy significant privileges and immunities both during their journey to and from the place venue of the meeting, and also while exercising their function. ${ }^{64}$ These include, in particular, immunity from personal arrest or detention and from seizure of personal baggage, and in respect of words spoken or written and all acts performed in their official capacity, as well as immunity from legal process of every kind which includes inviolability for all papers and documents.

\section{Freedom of Communications:-}

Similar to above individual rights, representatives of states or international organizations have the right to use codes and receive papers or correspondence by courier or sealed bags. Diplomatic immunity respects of their personal baggage are accorded to diplomatic envoys.

\section{Exemption from Fiscal Regulation:-}

The same facilities of organization in respect of currency or exchange restrictions as are accorded to representatives of foreign governments on temporary official missions. The only exception is that, they shall have no right to claim exemption from customs duties on goods imported (otherwise than as part of their personal baggage) or from excise duties or sales taxes.

\section{Exemption from immigration restrictions, alien, registration or national service obligation:-}

As per article 4 section 11(d) of the general Convention the representative of member state in respect of themselves and their spouses, are exempted from immigration restrictions, registration or national obligations in the state they are visiting or through which they are passing in the exercise of their functions. In event of violation of the privileges and immunities, the traditional diplomatic relations shall apply. ${ }^{65}$

\section{Immunities and Privileges accorded to UN staffs:- Theoretical and Legal base:-}

The privileges and immunities which are extended to UN staff is the continuation of autonomy of the UN organization to administer its staff. Since a legal person cannot act without human agency, the privileges and immunities granted to UN Organizations are extended to the UN staffs and officials. If the personality of staff is violated due to detention, this would affect the normal functions of the organization.

\section{Persons Exempted:-}

All staffs irrespective of rank, nationality and place of work, except those employed on hourly basis, without distinction between international staff and local staff benefited from immunity and privileges ${ }^{66}$ A limited category of officials like the UN Secretary General and Assistant and Secretaries General are accorded the privileges, immunities, exemptions and facilities granted to diplomatic immunity in accordance with the international laws. They enjoy the highest degree of privileges and immunities. ${ }^{67}$

\section{Immunity from Legal Process:-}

Allofficialsoftheorganizationenjoyfunctionalimmunityfromlegalprocessinrespectofwordsspokenorwrittenandinresp ectofallactsperformedbythemin theirofficialcapacity. ${ }^{68}$ Their personal baggage is also exempted from seizure, search, and they are accorded to diplomatic envoy. The scope this immunity does not cease with the cessation of functions. ${ }^{69}$ The officials' family enjoys immunity from criminal jurisdiction and seemingly since they have no official duty to perform, they are not exempted from civil jurisdiction of the host country. Today, anyone covered under the Convention is immune from any "legal process". This means that they can neither be prosecuted for a crime, nor required to cooperate with an investigation, hand over evidence or testify in court, unless that immunity is waived by the Secretary-General. ${ }^{70}$

Freedom of Communication, Exemption from Immigration Restriction, Registration or National Obligation:For the purpose of communication with the UN, the United Nations staff uses codes and receives papers or correspondence by courier or in sealed bags. All United Nation Staffs are exempted from immigration, taxation, custom duties, currency restrictions, and national service obligations. ${ }^{70}$ The scope exemption from immigration restriction is also extended to the UN staff's spouses and dependents. ${ }^{71}$ They are exempt from taxation on their salaries and emoluments paid to them by an organization, and have privileges in respect of exchange and 
repatriation facilities intimes of international crises. Officials have the right to import their furniture and effects free of duty at the time of first aking up their post in the country in question. ${ }^{72}$

\section{Waiver of Immunities and Privileges of UN agencies:-}

The true bases for immunities and privileges accorded to UN organizations are that they are necessitated by the effective exercise of their functions. But if its staffs involved in different legal proceedings, the UN may waive the above immunities and privileges in the event of legal proceeding instituted by or against it before a host country. ${ }^{73}$ The Convention specially provides the need to cooperate by the UN agencies with appropriate authorities of member states to facilitate the proper administration of justice and to prevent any abuse in connection with the privileges and immunities. Immunity from jurisdiction of the host country does not exempt the UN staffs from the obligations of respectingto national laws and liability. ${ }^{74}$ If an official's act contravenes the criminal law of host country, such official is required to undergo legal process with adherence of proper procedures of waiver of immunity. For this, the UN agency has to examine whether the alleged act falls within the scope of official duties or not. If the alleged act does not fall within the official duty, the privileges and immunities will be waived. The law enforcing organ, in order to enforce law, seeks the waiver of immunity by making request through proper channel, that is, through MoFA.

In this case, verification of identity or stopping temporarily for the purpose of checking documents may not constitute arrest or detention. The request for waiver is decided by higher level upon the fulfillment of some grounds for commission of crime. In order to identify the persons who are entitled the privileges and immunities of an international organization, there is an identity card that is issued by the host country. ${ }^{75}$ In case where there is imminent and grave danger of public safety, the law enforcing organ may intervene to the extent necessary to stop the commission of such crime. A host country, again issues a distinctive plate for the UN vehicles to assist the law enforcing organ in identifying vehicles which belong to the UN and its officials. ${ }^{76}$ The $\mathrm{UN}$ agencies may be required to inform the competent authority in case they want to transfer the plate from the assigned vehicle to another.

\section{Obligation to offer Alternative Dispute Settlement Mechanism:-}

Article 8 Section 29 of the Convention permits the UN Organization to settle disputes with claimants of host country. It imposes an obligation on UN agencies to arrange an alternative mode of settlement of civil disputes. ${ }^{77}$ Section 29 states that, "The United Nations shall make provisions for appropriate modes of settlement of dispute arising out contracts or other disputes of a private law character to which the United Nations Organization is a party, and disputes involving any official of the United Nations who by reason of his official position enjoys immunity, if the immunity has not been waived by the Secretary-General.",78

This provision obliges the UN to create a platform for dispute settlement with reared to claims of private entities, which would otherwise, due to the absolute immunity of the UN, have no legal means of perusing their interests. ${ }^{79}$ But here what does appropriate mode of settlement available for those who are injured is not clear. Although the convention does nots pecifically provide amechanism to deal with claims brought against officials who have actedinan official capacity, and whose immunity has not been waived, it does state in article VIII, Section 29that the UN will make provisions for appropriate forms of settlement. Thus, under the UN frame work, the organization makes settlement available for claimants who have been injured by UN officials who enjoy immunity. ${ }^{80}$

When a dispute involves a UN official who has acted in a private capacity, waiver is not an issue because official is in the same position as any other private individual. The objective of this arrangement is to balance immunities of UN against the right to access to justice of claimants. The presence of these alternative modes of settlement of disputes reduces the tension between the organization's enjoyment of immunity and the resulting unavailability of judicial remedies for the settlement of disputes between the organization and other parties. ${ }^{81}$ With respect to disputes arising out of contracts, there is a practice of insertion of a standard arbitration clause in such contract. ${ }^{82}$ The UNCITRAL Arbitration Rules are widely accepted for inclusion in contracts. Tort cases can also be settled with negotiation or mediation without undergoing a host country judicial jurisdiction as the phrase 'private law character' is so wide and includes the non-contractual cases. ${ }^{83}$

\section{The Extent of Immunities and Privileges of UN Organizations:-}

The immunity and privileges granted to UN organizations is based on functional approach. The reason for granting immunities to UN agencies was to enable them to pursue their functions more effectively and to permit organizations to operate free from unilateral control over the organization by the host country. But the question is 
how we measure the level of immunities and privileges in light of such functional necessity? The powers and limits of UN organizations depend on the constitution of the organization in which the member states entrusted to it.

The scope of the organization has been limited in the constituent document, and thus, it cannot go beyond the limit. The UN while creating this organization limits their powers and functions either expressly or impliedly. Thus, a UN agency operates with the ambit of powers and functions given expressly in the constitution document or referred impliedly those powers which deemed necessarily for the fulfillment of the tasks which have been assigned to it. The test to its extent of privileges and immunities will be whether such privileges and immunities are associated with effective performance of its functions or only limited to the fulfilling of the purposes of the organization.

\title{
Problems in Implementation of Immunities and Privileges of UN Agencies in Ethiopia:-
}

The immunities and privileges of UN agencies was a long established component of international law that bestows upon the staffs and immediate exemption from the jurisdiction of local courts and other government systems on their actions as carried out on behalf of their organizations. The formulation of immunities and privileges under the 1946 convention was a vindication of the importance of facilitating peaceful relations between host states and UN agencies. While these laws on immunity have been widely accepted as necessary for the conduct of functions, the apparent abuse of this immunity by scoundrel officials and the seemingly lack of countermeasures in this law has fostered a growing debate as to the flaws of the convention and the right justice of individuals. This part of the article will assess the legal and practical shortcomings in implementation of immunities and privileges of UN agencies in Ethiopia and evaluates available remedies.

\section{Legal Problems:-}

As already discussed, section $2 \& 3$ of the Convention bares courts and other justice organizations from exercising jurisdiction concerning cases involving UN agencies. This creates a vacuum of alternative legal remedy available for individual to seek justice. The inadqency of the mediation process arranged in MoFA leads to two legal problems. This is absence of domestic immunity act towards international organizations and non domestication of the general convention. On the other hand, it creates some practical problems like, inadequacy of effective and guaranteed alternative dispute settlement mechanism for abuses committed as a result of lack of awareness and access to justice, and reluctance towards international organization in the absence of clear understanding.

\begin{abstract}
Absence of Diplomatic Immunity act:-
United Nations was established in 1945. A year after its establishment, the UN adopted the General convention on 13 February 1946. Ethiopia was among founding members of United Nations. After adoption of the Convention it acceded on 22 July $1947 .{ }^{84}$ In addition to this, Ethiopia is a party to the 1961 Vienna Convention on Diplomatic Relations and signs many host country agreements with UN and its agencies. Ethiopia is among the centers of multilateral diplomacy in the world next to Switzerland and USA by hosting different diplomatic mission of state and international organizations. ${ }^{85}$ Even though Ethiopia acceded to the Convention yet now the country lacks a comprehensive domestic immunity act which governs the relationship between its citizens with diplomatic missions including UN agencies. So in order to solve some legal and practical problems practically domestic immunity act is very important for countries like Ethiopia to facilitate smooth relationship with the whole diplomatic community.
\end{abstract}

Concerning this both Ato Besifat Gashaw and Ato Samson Abebe agree that absence of immunity act is one legal problem in Ethiopia not only for UN agencies but also for other diplomatic missions. In order to solve different cases that arises between diplomats and local claimants, and to protect fundamental right to justice of Ethiopians, enacting immunity act is necessary. Recently there is an effort by Ethiopian Ministry of Foreign Affairs to prepare a draft proclamation on immunities but yet now not finalized to be adopted by HPR. ${ }^{17}$ When we look in to the experience of some countries like Kenya and South Africa, they have immunity acts towards their diplomatic missions. ${ }^{86}$

In Kenya, the immunity and privileges Act (cap 179) gives the force of Kenyan law to relevant provisions of within the conventions. ${ }^{87}$ This applies to all foreign diplomatic and consular missions. International organizations like UN agencies negotiate diplomatic immunity and privileges right for their staffs under special arrangements. ${ }^{88}$ In addition, Kenya is a party to both 1946 Convention on immunities and privilege of UN and 1961 Vienna convention on diplomatic relation. They are immune from suits and legal processes. ${ }^{89}$ In Kenya, when dispute arises as result of

\footnotetext{
${ }^{17}$ See, supera note, at 153 and 159.
} 
abuse of immunities and privileges it solved by negotiation with parties. ${ }^{90}$ Similarly, South Africa had diplomatic and privileges Amendment Act 35 of $2008^{91}$ and a party to the 1946 and 1947 convention on immunities and privileges of UN and its specialized Agencies. ${ }^{92}$ According to section 24 of the act when abuse of immunity and privileges occurred; consultations shall be held between the state and agency.

\section{Problem of Domestication of the Convention:-}

Even though Ethiopia lacks domestic immunity act, there is a problem of implementing the already existing convention because of different reasons. As per article 9(4) of FDRE constitution, all international agreements ratified by Ethiopia are an integral part of the law of the land. ${ }^{93}$ International agreements are signed by the executive branch of the government. But the question is how these international agreements are going to be part of domestic law of the country? As far as domestication of international treaties in Ethiopia is concerned, there are two ways of by which treaties can be part of law the land. ${ }^{94}$ The first one is by ratification of the treaties by HPR. For those treaties which impose strong political, economic, security and financial obligations on the country, they pass through ratification process. ${ }^{95}$

According to Ato Besfat, such conventions pass many steps to be part of Ethiopian law starting from Ministry of Foreign Affairs up to HPR. First the legal experts of Ministry of Foreign Affairs prepare explanation on the convention and bring to the board of the Ministry for discussion, after the debate made up on it, it will send to Council of Ministers, and then the Council of Ministries sends it to HPR legal standing committee for further discussion. Finally up on ratification by HPR it proclaimed on Federal Negarit Gazeta proclamation No 3/1995.

The second way of domestication on international treaties is by simple signature. Ato Besifat Gashaw argue that, for those treaties which does not put strong legal and political obligation on the county, they can be part of the law the country only by signature and does not goes through ratification process of HPR. For example agreements to establish diplomatic relations, bilateral trade and loan agreements and host country agreements are the main once. ${ }^{96}$ This agreement does not go though ratification process of HPR and the full text is not proclaimed on official Law Gazzet. Ethiopia had two ways of domestication procedure practically, but when we look the convention on immunities and privileges Ethiopian acceded in 1947 during the imperial regime, yet new now the convention was not published (domesticated) on Federal Negarit Gazeta proclamation No 3/1995.

One of the main legal problems in the enforcement of the convention on immunities and privileges of UN agencies in Ethiopia is luck of awareness and judicial notice on the convention by law enforcing organs due to nonpublication of the convention on Federal Negarit Gazeta proclamation. The convention was deposited in HPR and MoFA and yet not disseminated to justice organ. It was also not translated to working language of courts. However article 2(2) of the Federal Negarit Gazeta proclamation No 3/1995 stated that "All laws of the Federal government shall be published in the Federal Negarit Gazeta ${ }^{97}$ and all Federal or Regional legislative, executive and judicial organs as well as any natural or juridical person shall take judicial notice of laws published in the Federal Negarit Gazeta". The full test of the general convention was not proclaimed on the proclamation, so it is difficult for judges to easily access it. ${ }^{98}$ According to Ato Besifat the reason for non publication of the convention was simply the customary practice of the country towards international treaties. Practically when UN agencies involved in different disputes with local claimants in Ethiopia and sued by individual in courts they invoke immunity from any legal process by basing their argument on the convention but judges are not aware whether they have immunity or not because of the non-publicity of the convention. So in order to have a judicial notice on the 1946 Convention, the proclamation obliges the convention to be published on Federal Negarit Gazeta. Some judges argue that the convention on immunities and privileges of UN agencies was not published on the Federal Negarit Gazeta, so it does not have the status of law of the country. ${ }^{99}$

\section{Host Country Agreement Problems:-}

In addition to the 1946 Convention on the immunities and privileges of UN, each agency sign a host country agreement with host state before they enter to function. When a state enters in to a head quarter agreement with UN agencies, it is allowing the organizations to operate in its territory. For example an agreement between the office of the United Nations high commission for refugees and the government of Ethiopia concerning of a regional liaison office for Africa of the high commission in Addis Ababa( UNHCR) July 7, 1966 and an agreement between the government of Ethiopia with United Nations Development Program (UNDP) February 26, 1981. After this the hosting country is under obligation to respect the autonomy of the UN organization to function in its territory. Host 
country agreements most of the time signed between organization and Ministry of Foreign Affairs of hosting country. ${ }^{100}$

Due to less commitment on the government side to implement both the convention and host country agreements, different problems are occurred in different parts of the country. According to UNDSS report from 2012 up to 2014 , 53 UN staffs were arrested and detained by Ethiopian judiciary and law enforcing authorities. ${ }^{101}$ Interview with legal offers of UNDP, UNHCR, UNCEF and IOM shows that arrest and detention of UN staffs has been happened without following the proper procedures. The privileges and immunities which are granted to UN are extended to UN staffs. In civil cases discussed below, courts applied Ethiopian laws on UN System Organizations. Though the Courts relied on the Article 70 (1) of the Civil Procedure Code, which allows ex-parte hearing, it does not work out in the international cases. ${ }^{102}$

\title{
Lack of awareness:-
}

One of the practical problem in enforcement and protection of immunities and privileges of UN agencies in Ethiopia is lack of awareness on immunities and privileges by law enforcing organs like police, prosecutors, courts, and other government organization. ${ }^{103}$ Especially courts and police officers have no a judicial notice on the convention due to non domestication of the convention which resulted in violation of the convention and difficult to balance the interest of UN agencies staffs and private claimants in resolving cases. ${ }^{104}$

\begin{abstract}
Absence of Effective and Guaranteed Dispute SettlementMechanism:-
Due to immunity from any legal processes, the Convention on article 8 sections 29 permits the UN and its agencies to settle disputes with claimants of host country. It imposes obligation on UN agencies, their officials who enjoy immunity and host country claimants to settle civil disputes of private law character. The objective of this arrangement is to balance immunities of UN agencies against the right to access to justice of Ethiopian claimants. Judge Girma Gebeyehu explains that many individuals are suffering from application of immunities and privileges of UN agencies in Ethiopia.
\end{abstract}

He states that many citizens brought their cases before courts to seek justice but courts are barred from exercising cases that involve UN agencies by the general convention. So the only option available for them is to seek their claim from UN agencies or officials through mediation processes arranged in Ministry of Foreign Affairs, immunities, privileges and protocol protection directorate section. ${ }^{105}$ The mediation mechanism is an informal processes and which lacks legal ground and does not render any written awards to complaints. ${ }^{106}$ Mostly tort (compensation), house rent, private employment relation, illegal parking, traffic accidents and tax cases can be settled with mediation without undergoing a host country judicial jurisdiction as the phrase "private law character" is so wide and includes the non-contractual matter. ${ }^{107}$ The involvement of Ministry of Foreign Affairs in settling disputes that arise between UN Agencies and individuals raise different questions. The first one is the legal ground of Minister of Foreign Affairs do such activities? The Ministry of Foreign Affairs is one the executive branch of the government which facilitates foreign relation of the country. But the issue of resolving individual claims that involve UN agencies and its officials is an issue which got solution by courts, so how can the Ministry of Foreign Affairs can adjudicate individual complains like national courts in line with the power and duty of MoFA. ${ }^{108}$ Concerning its legal ground there are two line of argument. Ato Samson Abebe said that, the Ministry of Foreign Affairs lacks explicit proclamation, regulation or directive for mediation processes to solve complain of individuals.

There is no standard and formal procedure for the mediation processes. But in order to fill the problem of absence of alternative effective remedy to individuals settling disputes takes place in informal way by customary practice of negotiation. ${ }^{109}$ The mediation section is arranged to help Ethiopian citizens by the ADR means in the absence of formal court litigation. On the other side Ato Besifat Gashaw argues that even though there is no direct relevant law concerning this, the Ministry of Foreign Affairs has the power to do such activities by proclamation of Foreign Service No 790/2013 article 3 (7). ${ }^{110}$ According to this proclamation the Ministry has the power to "Respond to issues and concerns raised in relation to the implementation of the international and regional human rights instruments ratified by Ethiopia, in consultation, as appropriate, with the relevant executive bodies; preparing the national implementation reports on these instruments, by coordinating the relevant executive bodies and stakeholders, and submit them to the appropriate international and regional bodies". ${ }^{112}$ The proclamation which provides the power and duties of MoFA No 4/ 1995 article 25 (9) states that, "the Ministry has the duty to ensure the privileges and immunities of foreign diplomatic missions and representatives of international organizations under international law and treaties to which Ethiopia is a party are respected". ${ }^{113}$ 
The second problem is the question of effectiveness and accessibility of mediation processes. According to Ato Samson Abebe and Ato Besifat Gashaw, the mediation mechanism is not effective and accessible like court decisions. It is mainly depend on the consent of the immunity holder UN officials and staffs. The MoFA have no administrative mechanism to compel UN agency officials if they are not willing to negotiate with claimants. ${ }^{114}$ Since the mediation processes is only found in Ministry of Foreign Affairs main office on Addis Ababa, it is not easily accessible for individual claimants especially from different parts of the country. ${ }^{115}$ The mediation is somewhat lead by the Ethiopian civil procedure code but not as such formal. In general due to absence of skilled manpower in the mediation processes, absence of cooperation on side of UN agencies, insufficiency of compensation or redress, lack of awareness by individuals and difficulty to execute the out came of the case, the mediation processes is not effective and efficient remedy for Ethiopian citizens. ${ }^{116}$

\section{Possible Remedies for abuse of Immunities and Privileges in Ethiopia:- Mediation:-}

Vast majority of protected persons do not abuse their immunity. But when abuses are occurred to individuals due to lack jurisdiction of courts, the main available remedy for claimants are solving civil disputes by mediation processes in Ministry of Foreign Affairs. The immunity, privilege and protocol, protection Directorate General Section in MoFA tasked to resolve civil disputes that arise between diplomatic missions and international organizations with Ethiopian citizens. ${ }^{117}$ The mediation process started when a complainant brought his application in written form to the mediation section. The written application must be in English and the claimant states the circumstance giving rise to his claim, the damage sustained or the claim and attaches evidences to prove the case. ${ }^{118}$ After receiving complains, the mediator assesses the claim and evidences, then after wrote a later to concerned UN agencies or official to give response on the case. Most of the time UN agencies are not willing to give response in written form; they prefer to give response orally.

The goal is to help Ethiopian citizens to get redress or justice by the ADR system. ${ }^{119}$ Bitannia explain that, when the mediator section wrote a letter to concerned UN agencies or an official enjoying immunity, first attempt to negotiate and settle the claim amicably with the claimant and if the parties fail to do so, the mediation processes will continue. If the conflicting parties resolve the case, no mediation will take place. However, the conflicting parties sometimes fail to agree. When the two parties cannot resolve the dispute themselves, the mediation section will arrange a schedule to mediate the parties. ${ }^{120}$ In criminal cases they are immune from any legal processes by $1961 \mathrm{Vienna}$ convention.

Only for civil cases that this mediation arrangement is applicable because of article 8 Section 29 of the 1946 Convention which imposes an obligation to settle disputes arising out of "private law character". When UN agencies or their officials are sued by individuals on courts before they came to negotiation, they ask the Ministry of Foreign Affairs to intervene and stop courts not to entertain the case, and then the Ministry wrote a letter to courts to close the case ${ }^{121}$ which is against judicial independence. The most important question arsis here is that what if both parties fails to agree by the mediation processes? Can the mediator give a binding decision?

Concerning this Ato Samson Abebe and Ato Besifat Gashaw states that, most of the time many cases are solved by the negotiation but few cases are delayed and not solved. The mediator cannot give a binding decision when they fail to agree but it propose the solution to pay some amount of compensation and bring the case to the directorate of international law affaires; then if it is grave it refers to the Ministry for final decision and sometimes it is difficult to execute. There is no appeal system like court's decision because mediation is an ADR mechanism which resulted in a win-win solution. The mediation processes is not effective and efficient solution to Ethiopian citizens but it is preferred to fill the gap absence of formal court litigation. ${ }^{122}$ Among cases entertained through mediation let us see few cases.

\section{Case 1:-}

An Ethiopian who was employed as a driver in UNHCR claimed that he was unlawfully expelled from work. He applied to the mediation section of Ministry of Foreign Affairs on September 23, 2014. He requested to get severance payment and compensation as per Proclamation No 377/2003. At the end of the mediation process, UNHCR agreed to pay severance payment only. Hence, the other claims of the claimant couldn't be settled. 


\section{Case 2:-}

International organization for migration (IOM) rented a house for office from an Ethiopian woman called Almaze Belay. Once the term of the contract was over, the house was transferred to the owner. However, in her application submitted on 31/5/2013, the owner claims that the organization failed to repair the damages it caused to the house. Moreover, she claimed that due to the damage caused by the IOM, she couldn't rent the house for four months. Therefore, the woman in her application to the mediation section requested a total of 106,517 Birr as compensation from the organization. The mediation section contacted the agency and mediated the two parties to solve the case. However, IOM refused to pay the requested amount of money. Therefore, the owner of the house was unable to get a redress.

\section{Case 3:-}

An official working in UNCEF injured a pedestrian while driving his car. The medical report confirmed that the victim has sustained $20 \%$ permanent disability. The victim claims that he has not received a proper treatment and he still suffers from the injury. The insurance company has paid 37,000 Birr for the treatment. However, the claimant asserts he needs to be compensated for the $20 \%$ permanent disability he sustained. The insurance company has refused to fully compensate the claimant by asserting that the official injured the person while discharged his obligation. Therefore, the claimant has resorted to the official to pay remained compensation. However, the claimant has not been compensated yet because of unwillingness of the official for mediation.

\section{Requesting for waiver of Immunity:-}

The second mechanism to secure remedy to claimants is wavier of immunity in order to entertain the claim by domestic courts. When UN agency staffs committed grave crimes and violated social norms the Ministry of foreign affairs can request UN secretary General to waive immunity as per article 2 of the Convention. ${ }^{123}$ Waiver is important mechanism used by the Convention to assure accountability. It adds another layer of protection to potential litigants. ${ }^{124}$ They are first protected by the doctrine of functional immunity itself, in addition, waiver is available remedy when justice so requires. Waiver is requested in rare instances but it was not employed due to reluctance of Ethiopian government.

\section{Declaration of Persona Non Grata Principle:-}

The Vienna Convention provides for a host state to declare a diplomat persona non grata in the event of grave violations of diplomatic privilege and immunity. ${ }^{125}$ Usually, grave crimes committed by diplomatic agents and other staffs of missions lead to a declaration, if waiver is not granted. ${ }^{126}$ If the UN didn't waive the immunity or did not gave response to our request, the last measure of the hosting state is to declare the person "persona non grata principle" 127 to expel the official from the country. This principle is not found in the 1946 Convention but it is found in 1961 Vienna Convention on diplomatic relations which got the status of customary international law.

\section{Adjudication of Abuses of immunity by Courtsin Ethiopia:-}

This right to access justice is a fundamental human right. The effective exercise of this right means, individuals can bring a suit before a court of law to get any remedy. Immunity of UN agencies, however, prevents individuals from getting any kind of remedy from a court of law or administrative tribunal by protecting officials and other staffs of agencies from the jurisdiction of the receiving state. The only available avenue for the aggrieved parties is to resort to the MoFA in case of traffic accidents and illegal parking. Recently due to lack of effective dispute settlement mechanism available to claimants, Courts are entertaining disputes that involve UN agencies. Some scholars describe this ongoing process as "radical approach", because of such Courts awarded meticulous consideration towards the examination of human right impact. ${ }^{128}$ The judgment in the cases of Medina Hussein vs. UNHCR and Alemayhu Olana vs UNDP are manifestations of human right approach. ${ }^{129}$

\section{Medina Hussein Vs UNHCR:-}

UNHCR Assosa filed office car code No 0583 killed an Ethiopian engineer called Ahmed sied on 1 August, 2012 in Assosa town on main road. Due to death of her husband by the car accident his wife Medina Hussein on February, $1^{\text {st }} 2013$ sued both UNHCR Assosa filed office and the car driver Ato Tarekegne Teferi jointly and severally on Assosa Zone High Court to pay compensation of birr 2,069.925 for death of her husband. When he dies he was 32 years of age and earns 6899.75 birr per month. UNHCR does not give response to the Court after receiving summon. Then after, Assosa Zone High Court entertain the case in the absence of UNHCR by Article 70 of the Civil Procedure Code which allows the ex-parte hearing if it is proved that the summons was duly served to the 
defendant. ${ }^{130}$ Finally the Court on April 8, 2014 gives judgment on UNCHR to pay birr 666, 331 compensation to Medina Hussein.

On June 5, 2014 Medina Hussein brought her application for execution of the judgment rendered by Assosa Zone High Court by her lawyer based on article 378 of the civil procedure code of Ethiopia. ${ }^{131}$ After receiving her application for execution of the judgment, the Court orders Commercial Bank of Ethiopia Assosa branch to pay 666, 311 birr to Medina Hussein from deposit account of UNHCR Assosa filed office. The bank was not willing to pay the money because; Ministry of Foreign Affair orders the bank not to pay the money by official letter. On June 28, 2014 MoFA wrote a letter to the Court which says UNHCR is one of UN agency which has immunity and privileges by 1946 Convention which Ethiopia is a party, so the Court have no jurisdiction to entertain Medina Hussein case. It orders the Court to stop adjudicating the case by referring to mediation in MoFA.

After receiving the letter, the Court closes the case on October 29, 2014 by majority vote by saying that they are immune from any legal processes based on article 2 (2) \& article 8 section 29 of the Convention. On the other hand the dissenting judge argue that it is against fundamental human right to fair trial and the right to get justice as per article 37 (1) of FDRE Constitution. Medina brought her appeal to Regional state Supreme Court and it dismiss decision of the majority vote of the High Court and confirm the judgment of the dissenting judge on January 14, 2015 by arguing that even though UN agencies are immune from any legal processes by the Convention, there is no effective remedy available to her to got justice. Even though the bank is not willing to pay the money from UNHCR deposit account the execution process continued in the Assosa High Court. The Court rendered six moth imprisonment on the Manger of the bank because of he is not willing to execute order of the Court. Finally the Court ordered UNHCR car to be sold by public auction to pay the compensation. Then UNHCR started to negotiate with Medina to pay the money in front of the Court and finally agree to pay the money without going to mediation of MoFA. Even though the Court lack of jurisdiction to adjudicate the case, it applies domestic law on international matter to give decision on the case. But from this judgment we can understand that the Court dismisses the immunity of UNHCR in order to protect the fundamental right to justice. The Court left the respect to UN agencies immunity and voiced the opinion that injustice will happen to Ethiopian citizen in the absence of effective dispute settlement mechanism.

\section{Alemayheu Olana Vs UNDP:-}

An Ethiopian, called Alemayheu Olana who have been employed by the UNDP was unlawfully fired from his job in 2013. He initiated his case to Yabelo Wereda Court and claimed to be reinstated to his job, get severance payment, compensation and certificate of work as per labor proclamation No 377/2003. ${ }^{132}$ The Wereda Court rendered decision in favor of him in the absence of UNDP to return him to his job and to be payee different payments as the labor proclamation. He continued to execute the judgment by Wereda Court. But the Wereda Court understands that it has no jurisdiction to entertain the case then, it closes the case by invoking article 2 (3) of the 1946 Convention. Ato Alemayheu brought his appeal to Borena Zone High Court but, the court dismisses his appeal by confirming the decision of the Cereda Court. Then he brings appeal to cassation of Oromia Supreme Court by assuming that fundamental error of law has been happened. The cassation bench gives the same ruling with that of Borena High Court.

Finally he appeals to cassation bench Federal Supreme Court in 2014 by saying that, though UN agencies are immune from any legal process, it is against Constitutional right to justice in the absence of internal dispute settlement mechanism within UNDP and absence of effective remedy in MoFA. The Court rejects his appeal and confirms the judgment of lower Courts on November 19, 2015 by saying that, UN agencies are immune from any legal processes by the 1946 Convention which Ethiopia is a party. The court argue that employment relation between Ethiopian citizens and foreign diplomatic missions or international originations operating within the territory of Ethiopia is not governed by labor Proclamation as per article 3 (3) a. ${ }^{133}$ In the judgment the court emphasis that to avoid injustice to Ethiopian citizens there is a mediation arrangement in MoFA.

Ato Alemayehu last option to seek justice is applying to Ministry of Foreign Affairs mediation section for negotiation with UNDP. He brought the case to mediation section by stating that he was unlawfully fired from his work and seeks to get severance payment, compensation, and unpaid salary of seven months. ${ }^{134}$ After many negotiations, UNDP was willing to pay 20,000 Ethiopian birr only. ${ }^{135}$ After he exhausted two ways to protect his right to justice, Alemayehu was dissatisfied with the decision of Courts and mediation in MoFA. Now he was forced to submit his application to Constitutional Inquiry Commission in House of Federation, by raising Constitutional 
right to get justice and fair trial in Ethiopia is affected due to immunity of UN agencies in the absence of effective remedy as per article 37(1) of the FDRE Constitution. ${ }^{136}$ In his application to the HOF Alemayehu, explain that the decision of courts and the mediation process in MoFA are unconstitutional which needs interpretation. The issue is currently pending in House of Federation of Ethiopia. ${ }^{137}$

\section{The Implication of Adjudication of Disputes Involving UN Agencies by Courts:-}

UN agencies are under obligation to provide dispute settlement mechanism to local claimants by section 29 of the Convention. In the absence of internal dispute settlement mechanism within agencies and ineffective and un-granted mediation to Ethiopians, leads to seek redress against UN agencies in courts depends on the claimants factual exhaustion of the remedies provide by organizations; unless it leads to absolute immunity which is against functional immunity of UN agencies. In the above two civil cases both UNDP and UNHCR neither provide an internal alternative dispute settlement mechanism nor give response for both Ethiopian claimants as per the Convention though these remedies are available theoretically. In the Medina Hussein case Asossa zone high court dismisses immunity of UNHCR in favor of her claim by understanding the absence of effective legal remedy available to her from practical perspective. On the other hand in the Alemayehu Olana case the Federal Supreme Court rejected his claim by assuming that the mediation in MoFA was effective remedy to seek justice.

This ongoing development of courts of Ethiopia regarding application of UN agencies immunity and right of local claimants is evolving from absolute immunity towards being conditional availability of dispute settlement mechanism. More recently this view has further shifted towards the position that available dispute settlement mechanism should also be a guarantee to claimants. The choice of courts as venue for disputes settlement of Ethiopian claimants seeking relief from UN agencies will probably lead to a fragmentation of jurisprudence of laws. ${ }^{138}$ Judge Alebachew Gida explains that reasonable shielding the weaker individual against overwhelmingly superior entities may seem, the object and purpose of UN organizations immunity should neither be underestimated nor fully forgotten. However, this appropriation of jurisdiction by domestic courts might expedite the ongoing development process within the UN agencies about providing effective legal remedies for non-staff members. ${ }^{139}$

\section{Availability of UN Internal Dispute Settlement Mechanisms:-}

UN agencies are obliged under Section 29 of the Convention to provide alternative dispute settlement mechanisms to individuals for the purpose of countering lacks of judicial redress which arise in connection with UN's immunity. A considerable part of claims lodged against the UN are employment related claims, i.e. claims by UN personal against the UN agencies. In order to accord this group of individual with a method of dispute settlement, an internal judicial system was created. ${ }^{140}$ However; it is paramount importance to note that these internal dispute settlement mechanisms are only accessible to staff members of UN agencies. The reasons why the internal justice system is only available to staff members is primarily a question of funding. ${ }^{141}$ A legal officer of UNDP, UNHCR and IOM explains that all UN agencies in Ethiopia have internal dispute settlement mechanisms available for internal staffs only. ${ }^{142}$ The only available dispute settlement mechanism for non staff members is Ad hoc arbitration tribunal for some commercial and contract issues. ${ }^{143}$ Until July 2009, the UN Administrative Tribunal (UNADT) assumed jurisdiction over disputes between staff members and the administration. The UNDAT's statute did not encompass jurisdiction concerning non staff members, ${ }^{144}$ although in some cases, the tribunal assumed jurisdiction because non-staff members had no other means of remedying their claims.

In July 2009, a new, two-tiered internal justice administration mechanism replaced the UNDAT. The UNDT and UNAT were created, thus establishing a faster, cheaper and more flexible system. This change effectively narrows the scope of jurisdiction in comparison to former system with regard to non staff members. This is true because the assertion of the UNGA concerning the restrictive interpretation of the statute has led the newly created tribunals to reject all claims of non-staff applicants. ${ }^{145}$ Arbitration is the only recourse to justice of non-staff members of UN agencies. This leaves non-staff members with limited possibility to approach possible conflicts with the administration of UN agencies.

\section{Concluding Remarks:-}

In the past, UN immunity was regarded as absolute and uninfringeable. However, alsow and creeping process has changed the general understanding of the UN'simmunity from absolute to relative upon certain criteria. An important role in understanding this process is the fact that the drafters of the Charter envisioned the UN's immunity to be of only functional nature.In the following process of specification which was inherent to the establishmentof 
the UN, the immunity changed to become of defacto absolute nature. While this view is still respected in some jurisdictions and forms the core arguments of some judgments, the prevailing view to day is based up on the consideration of human rights,especially the individual right to judicial redress and the right of due process.

As a political capital of Africa and a host country of different diplomatic missions, nowadays it is necessary to have comprehensive immunity act that regulate and enhance smooth relationship with diplomatic missions particularly. A host country is under obligation to respect the autonomy of the international organization once it has concluded a treaty that permits the presence of organization in its jurisdiction. However, implementation of immunities and privileges of UN agencies in Ethiopia leads to legal and practical problems. Among these, lack of awareness on the Convention and Head Quarter agreements by justice organs and other administrative bodies, non-publication of the conventions and HQA to have judicial notice and absence of effective dispute settlement mechanism for claimants are the main problems. The infringement of human rights as the practical application of immunities and privileges is an obstacle to prevention of violation of human rights, limits the possibility of punishment of violators of human rights and it makes it difficult for victims to get sufficient remedy.

The mechanisms utilized to secure effective remedy to claimants are inadequate in Ethiopia except, mediation in MoFA. It is partly because national courts have become less reluctant to challenge the UN's once undisputed immunity that the process of judicial reform within the UN has gained considerable momentum. However, the status quo being that non-staff members may only seek legal recourse through rather costly arbitration proceedings,it can be expected that the "radical approach"ofsomenationalcourtswillnotendabruptly.Rather,itshouldbe expected that courts will continue to hold in favorof individuals who other wise would be confronted withdenialof justice.It is also possible tha tnational courts will continue to erode the UN's immunity in favor of further amelioration of judicial redress for individuals. The mediation arrangement was not effective and efficient and not easily accessible to individuals. Government was reluctant to request waiver of immunity and to declare persona non grata principle when persons enjoying immunity abuses human rights. The Convention impose obligation on UN agencies to settle disputes of private law character. But practically UN agencies are not willing to settle disputes of private law character with claimants. So the limited access to alternative dispute settlement mechanism available for injured claimants in Ethiopia leads to complete denial of justice.

Recently some courts are entertaining different cases that involve UN agencies by violating the Convention. Few Courts dismiss the immunity of UN agencies by favoring for claimants in the absence of effective remedy. On the other hand some courts dismiss the claims of individuals by favoring for UN agencies immunity and privileges. This ongoing development of choice of courts as venue for disputes settlement of Ethiopian claimants seeking relief from UN agencies will probably lead to a fragmentation of jurisprudence of laws. In order to facilitate smooth relationship between Ethiopia and the UN system Organizations and facilitate the work of the UN in the country respecting their immunity and privileges is crucial but Ethiopia citizen right to seek justice must be respected. Ethiopia should use the declaration of persona non grata principle against persons frequently commits serious crimes by abusing their immunity, if a waiver is refused.

However, care should also be taken not to harm the diplomatic relationship between Ethiopia and the UN agencies whose staff is declared persona non grata. It would be wise first to request a waiver by clearly showing the gravity of the crime and its implication for human rights and the fact that Ethiopia will be forced to declare the individual persona non grata so that the offender would be prosecuted in the sending state. Ethiopia, in collaboration with other countries, should diligently push for the refinement of the Convention or for preparing ways in which abuse of immunity could be curbed. For this, Ethiopia should actively participate in multilateral forums which could be a good to amend the general Convention or find other ways to find solutions for abuse of immunity. 